\title{
Honey roasted peanuts and roasted peanuts from Argentina. Sensorial and chemical analyses
}

\author{
By Marta G. Mestrallet ${ }^{1}$, Laura Carnacini ${ }^{2}$, María J. Días ${ }^{2}$, Valeria Nepote ${ }^{1}$, Liliana Ryan ${ }^{2}$, \\ Silvia Conci ${ }^{2}$ and Nelson R. Grosso ${ }^{1^{*}}$ \\ ${ }^{1}$ Química Biológica, Facultad de Ciencias Agropecuarias (UNC), ICTA, IMBIV-CONICET, \\ CC 509, 5000 Córdoba, Argentina. \\ ${ }^{2}$ Escuela de Nutrición, Facultad de Ciencias Médicas (UNC), 5000 Córdoba, Argentina. \\ * Author to whom correspondence should be addressed (e-mail nrgrosso@agro.uncor.edu).
}

\section{RESUMEN}

Maní tostado con miel y maní tostado de Argentina. Análisis químico y sensorial.

El objetivo del trabajo fue caracterizar química y sensorialmente al Maní Tostado con Miel (MTM) y Maní Tostado (MT). Estos dos productos fueron evaluados sensorialmente analizando su aceptabilidad por parte de consumidores (test de aceptabilidad) y sus atributos sensoriales por el uso de un panel de jueces entrenados (prueba descriptiva). Por otra parte se describió la composición química porcentual: porcentajes de proteínas, aceites, hidratos de carbonos y cenizas. Los contenidos de hidratos de carbonos, aceites y proteínas en MTM fueron de $28,22 \%$, $45.56 \%$ y $21,06 \%$. MT presentó mayores porcentajes de lípidos y proteínas y menor contenido de hidratos de carbono que MTM. EI valor energético total de MTM es levemente menor que en MT. La aceptabilidad de los productos mostró mayor número de consumidores que le asignaron un valor de 8 ( me gusta mucho) dentro de una escala hedónica de 9 puntos a MTM y de 6 (me gusta ligeramente) a MT. El panel de jueces entrenados describieron 11 atributos: color marrón, rugosidad, sabores a maní tostado, oxidado y cartón, dulce, salado, amargo, ácido, dureza y crujiente. La intensidad del atributo maní tostado fue mayor en MT que en MTM mientras que este último presentó mayor intensidad en los atributos rugosidad, dulce y salado.

PALABRAS-CLAVE: Aceptabilidad - Análisis sensorial - Arachis hypogaea - Composición química - Maní - Maní tostado con miel.

\section{SUMMARY}

Honey roasted peanuts and roasted peanuts from Argentina. Sensorial and chemical analyses.

The objective of this work was to characterize the chemical and sensory aspects of Honey Roasted (HRP) and Roasted Peanuts (RP). These products were evaluated for sensory analysis: overall acceptance using a consumer test and a descriptive analysis using a trained panel. Percentages of protein, oil, carbohydrate and ash was analyzed in HRP and RP. The contents of carbohydrate, oil and protein in HRP were $28.22 \%, 45.56 \%$ and $21.06 \%$, respectively. RP showed higher percentages of lipids and protein and lower percentages of carbohydrate content than HRP. The total energetic value was lower in HRP. Values of 8 (like very much) were chosen by a higher number of consumer panelist for HRP while values of 6 (like slightly) were found in a higher proportion for RP. The trained panel described 11 attributes: brown color, roughness, roasted peanutty, oxidized, cardboard, sweet, salty, bitter, sour, hardness and crunchiness. The roasted peanutty intensity in RP was higher than in HRP. The intensities of roughness, sweet and salty in HRP were higher than in RP.
KEY-WORDS: Arachis hypogaea - Chemical composition Consumer test - Honey roasted peanuts - Peanut - Sensory analysis.

\section{INTRODUCTION}

Peanuts are grown worldwide in the tropics and temperate zones primarily as an oilseed crop. Peanut seeds make an important contribution to the human diet in many countries, and their widespread acceptability is attributed to their economic value to the industry and their nutritional benefits to consumers (Bansal et al., 1993).

Peanuts are characterized by high oil and protein contents and a low percentage of carbohydrates and ash (Grosso and Guzmán, 1995). A large proportion of peanut production in the world goes into domestic food use, the end products being peanut butter, salted peanut products, confections, and roasting stock. These peanut-containing foods enjoy widespread popularity because of their unique roasted peanut flavor. The rest of the peanut production is utilized as an edible oil source of high quality. Peanuts are continually applied for the preparation of new and improved food products; thus, a more complete knowledge of their composition and flavor properties is desirable (Amhed and Young, 1982). The use of roasted peanuts in making different types of candies and confections is due largely to their pronounced flavor, crunchy texture and high protein content (Asiedu, 1994). Peanuts are sold fresh as a vegetable, canned, frozen, roasted in the shell, toasted and salted, used in more than 50 confections and bakery products, and are ground into butter for use in more than 100 recipes (Woodroof, 1983)

Peanuts are rich in energy. One kilogram of peanuts provides approximately the same energy value of 2 kilogram of beef, 1.5 kilogram of Cheddar cheese or 36 medium size eggs (Woodroof, 1983). Peanuts contain approximately $50-55 \%$ oil with $30-35 \%$ and $45-50 \%$ of the oil being linoleic and oleic acids, respectively, which becomes 
susceptible to development of rancid and off-flavors through lipid oxidation (St. Angelo, 1996). Lipid oxidation occurs during the storage of peanut products and contributes to the development of undesirable flavors in foods where peanuts are an ingredient. The oxidation reactions lead indirectly to the formation of numerous aliphatic aldehydes, ketones, and alcohols (Bett and Boylston, 1992). Simultaneously, off-flavors like oxidized, cardboard and painty increase in such peanut products (Gills and Resurreccion, 2000; Grosso and Resurreccion, 2002).

Edible coatings in peanut products may a) prevent moisture loss and oxygen diffusion, b) be used as a vehicle for additives such as antioxidants and flavoring agents, and c) improve consumer acceptance for applying flavoring (Baker et al., 1994). Honey roasted peanuts have a coating that is mainly a combination of honey and sugar. The effect of the honey coating on the peanut flavor and the sensory descriptive analysis is not known. The objective of this work was to determine the chemical composition, sensory description and consumer acceptance of honey roasted peanuts in comparison with roasted peanuts elaborated with Argentinian peanuts.

\section{EXPERIMENTAL}

\subsection{Materials}

Sound and mature seeds of blanched peanuts (Arachis hypogaea L.) type Runner, size 38/42 kernels per oz (2001 crop) were provided by the company, Lorenzati, Ruescht y Cia of Ticino, Córdoba, Argentina. Before processing, peanuts were inspected; damaged and bruised kernels were removed manually.

\subsection{Product Elaboration}

Roasted Peanuts (RP). Blanched peanuts were roasted at $140^{\circ} \mathrm{C}$ in an oven (Memert, modell 600 , Schwabach, Germany) for $30 \mathrm{~min}$. Peanuts were heated to a medium roast or an average Hunter color Lightness $(L)$ value of $50 \pm 1.0$ (Johnsen et al. 1988).

Honey Roasted Peanuts (HRP). This product was prepared with $85 \% \mathrm{RP}$ and $5 \%$ syrup solution and $10 \%$ dried-solid $\operatorname{mix}(\mathrm{w} / \mathrm{w} / \mathrm{w})$. A syrup solution was prepared consisting of $50 \%$ sucrose, $35 \%$ honey and $15 \%$ distilled water $(\mathrm{w} / \mathrm{w} / \mathrm{w})$. A dried-solid mix was prepared consisting of $70 \%$ impalpable sucrose, $20 \%$ impalpable salt and $10 \%$ corn starch. RP were placed into a stainless steel coating pan rotating at $28 \mathrm{rpm}$. Then a syrup solution was applied on the RP. Finally, dried-solid mix was poured into the coating pan to separate the kernels.

\subsection{Chemical analysis: oil, protein, ash, carbohydrate and moisture contents.}

Three samples of HR and HRP were examined for oil, protein, ash and moisture contents. Kernels of each sample were milled and oil was extracted for 16 $\mathrm{h}$ with petroleum ether (boiling range $30-60^{\circ} \mathrm{C}$ ) in a Soxhlet apparatus. The extracted oils were dried over anhydrous sodium sulfate and the solvent removed under reduced pressure in a rotary film evaporator. Oil percentages were determined by weight difference.

Moisture, ash and nitrogen contents were determined on a dry weight basis according to AOAC (1980). Ash determination was performed by incineration in a muffle furnace at $525{ }^{\circ} \mathrm{C}$. The nitrogen content was estimated by the Kjeldahl method and converted to protein percentage using the conversion factor 5.46 (Young and Hammons, 1973). Carbohydrate content was estimated by difference with the other values.

\subsection{Sensory Methods.}

Consumer Analysis. Panelists $(n=100)$ were from Córdoba (Argentina) and were recruited using the following criteria: ages between 18 to 65 , non-smokers, no food allergies, and eat roasted peanuts and/or peanut products at least twice a week. For sample evaluation, 5 grams of the peanut samples were placed into plastic cups with lids, coded with 3 digit random numbers. The 6 samples consisting of HRP and RP (two products $x 3$ replications) were tested on the same day and presented to panelists at random, (monadic) in order to avoid interaction between samples during the test day. Samples were presented with water and paper ballots on a plastic tray. Panelists were instructed to consume the whole sample and rinse their mouths with water between samples to minimize any residual effect. A 9-point hedonic scale ranging from 1 = dislike extremely to 9 = like extremely (Peryam and Pilgrim, 1957) was used to evaluate overall acceptance from HRP and RP samples.

Consumer preference as paired preference test was estimated using the information obtained from the acceptance test (Resurreccion, 1998).

Descriptive Analysis. Panel. A total of 12 trained panelists participated in the descriptive analysis of Honey Roasted Peanuts and Roasted Peanuts study. All panelists were selected on the following criteria: natural dentition, no food allergies, non-smokers, between the ages of 18-64, consume roasted peanuts and/or peanut products at least once a month, available for all sessions, interest in participating, and able to verbally communicate regarding the product (Plemmons and Resurreccion 1998). All panelists had to have a perfect score in a taste sensitivity test and the ability to identify 5 out of 
7 commonly found food flavors before they qualified as panelists.

Training. All 12 panelists were trained and calibrated for 4 days. Each training session lasted $2 \mathrm{~h}$ each day for a total of $8 \mathrm{~h}$. Descriptive analysis test procedures as described by Meilgaard et al. (1991) were used to train the panelists.

On the first day of training, panelist were given a review of concepts of sensory analysis. Then, they were asked to taste standard solutions of sucrose, sodium chloride, citric acid, and caffeine at varying concentrations and intensities that corresponded to points on a $150 \mathrm{~mm}$ unstructured line scale (Plemmons and Resurreccion, 1998). After that, all 12 panelists worked together to develop the language to describe perceivable product attributes in HRP and RP. Fresh and rancid samples of HRP and RP were presented to each panelist. Panelists identified appearance, aroma, taste and texture attributes that would be used to described the product samples. A lexicon for peanut samples (Johnsen et al., 1988) was used to provide an initial list of attributes. Panelists decided whether terms were redundant and should be removed or if additional terms should be included in the list of attributes and defined each attribute (Table I). Panelists also identified references to be used to rate each appearance, flavor, and textural attributes. Each panelist gave an intensity rating of each reference between 0 and 150 for each attribute. The mean intensity rating was calculated and used as an attribute in intensity rating for that particular reference (Table II).

On the second day of training, panelist reviewed descriptors, definitions, and reference standards to describe HRP and RP samples. Panelist tasted each

Table I

Definitions of attributes used by the trained panel to describe Honey Roasted Peanuts and Roasted Peanuts

\begin{tabular}{|c|c|}
\hline Attribute $^{1}$ & Definition \\
\hline \multicolumn{2}{|l|}{ Appearance } \\
\hline 1- Brown Color & The intensity or the strength of brown color from light to dark brown. \\
\hline 2- Roughness & The appearance associated with uneven surface. \\
\hline \multicolumn{2}{|l|}{ Aromatics } \\
\hline 3- Roasted Peanutty & The aromatic associated with medium roasted peanuts. \\
\hline 4- Oxidized & The aromatic associated with rancid fats and oils. \\
\hline 5- Cardboard & The aromatic associated with wet cardboard. \\
\hline \multicolumn{2}{|l|}{ Tastes } \\
\hline 6- Sweet & Taste on the tongue associated with sucrose solutions. \\
\hline 7- Salty & Taste on the tongue associated with sodium chloride solutions. \\
\hline 8- Bitter & $\begin{array}{l}\text { Taste on the tongue associated with acid agents such as citric acid } \\
\text { solutions. }\end{array}$ \\
\hline \multicolumn{2}{|l|}{ Texture } \\
\hline 10- Hardness & Force needed to compress a food between molar teeth. \\
\hline 11- Crunchiness & $\begin{array}{l}\text { Force needed and amount of sound generated from chewing a sample } \\
\text { with molar teeth. }\end{array}$ \\
\hline
\end{tabular}

Attributes listed in order as perceived by panelists. 
Table II

Standard reference and warm up intensity of attributes used in descriptive tests for Honey Roasted Peanuts and Roasted Peanuts

\begin{tabular}{|c|c|c|c|}
\hline & Reference & $\begin{array}{l}\text { Reference } \\
\text { intensity }^{1}\end{array}$ & $\begin{array}{c}\text { Warm up } \\
\text { intensity }\end{array}$ \\
\hline \multicolumn{4}{|l|}{ Appearance } \\
\hline 1- Brown Color & Cardboard (lightness value, $L=47 \pm 1.0$ ). & 61 & 44 \\
\hline \multicolumn{4}{|l|}{ Aromatics } \\
\hline 3- Roasted Peanutty & $\begin{array}{l}\text { Dry roasted peanuts (JL SA, Ticino, Córdoba, } \\
\text { Argentina). }\end{array}$ & 81 & 59 \\
\hline 4- Oxidized & Rancid peanuts. & 103 & 5 \\
\hline \multicolumn{4}{|l|}{ Tastes } \\
\hline 6- Sweet & $\begin{array}{l}2.0 \% \text { sucrose solution. } \\
5.0 \% \text { sucrose solution. } \\
10 \% \text { sucrose solution. } \\
15 \% \text { sucrose solution. }\end{array}$ & $\begin{array}{c}20 \\
50 \\
100 \\
150\end{array}$ & 16 \\
\hline 7- Salty & $\begin{array}{l}0.2 \% \mathrm{NaCl} \text { solution. } \\
0.35 \% \mathrm{NaCl} \text { solution. } \\
0.5 \% \mathrm{NaCl} \text { solution. }\end{array}$ & $\begin{array}{l}25 \\
50 \\
85\end{array}$ & 9 \\
\hline 8- Bitter & $\begin{array}{l}0.05 \% \text { caffeine solution. } \\
0.08 \% \text { caffeine solution. } \\
0.15 \% \text { caffeine solution. }\end{array}$ & $\begin{array}{c}20 \\
50 \\
100\end{array}$ & 7 \\
\hline 9-Sour & $\begin{array}{l}0.05 \% \text { citric acid solution. } \\
0.08 \% \text { citric acid solution. } \\
0.15 \% \text { citric acid solution. }\end{array}$ & $\begin{array}{c}20 \\
50 \\
100\end{array}$ & 2 \\
\hline Texture & & & \\
\hline 10- Hardness & Almonds (Grandiet, Córdoba, Argentina). & 61 & 52 \\
\hline 11- Crunchiness & Corn flakes (Granix, Buenos Aires Argentina). & 100 & 41 \\
\hline
\end{tabular}

${ }^{1}$ Intensity ratings are based on $150 \mathrm{~mm}$ unstructured line scales.

${ }^{2}$ Medium (lightness value, $L=50 \pm 1.0$ ) roasted peanuts (Blanched Runner).

reference and provided a rating for each one. The panel was calibrated by obtaining an average panel rating with a standard deviation within 10 points. Panelists not rating within \pm 10 points of the mean rating were asked to re-evaluate the sample and adjust their rating until a consensus was reached. After that, medium roasted peanuts were presented as a warm-up sample to be used for each panelist as the initial sample during training and testing sessions (Plemmons and Resurreccion, 1998).

On the third day of training, panelist finalized the definitions, descriptors, and reference standard intensities to describe HRP and RP. Then, The list of definitions (Table I) and warm-up and reference intensity ratings (Table II) were finalized. After that, panelists evaluated two RP samples elaborated with different degrees of roasting using paper ballots in order to calibrate themselves.

On the last day of training, panelists continued evaluating $2 \mathrm{HRP}$ and $2 \mathrm{RP}$ samples elaborated with different peanut varieties (Colorado and Runner) to practice and to calibrate themselves within 10 points of the mean ratings for each attribute of the samples.

Sample evaluation. The samples (2 products: HRP and $\mathrm{RP} \times 3$ replications) evaluated in descriptive analysis were the same that those used by the consumer test. The quality of the samples was homogeneous. RP and HRP were prepared with blanched peanuts, type Runner, size 38/42 kernel per oz, 2001 crop year and cultivated in the location of Ticino, Córdoba, 
Table III

Mean of centesimal composition and energetic value from Honey Roasted Peanuts (HRP) and Roasted Peanuts (RP)

\begin{tabular}{l|c|c}
\hline & RP & HRP \\
\hline Protein (\%) & $24.83 \pm 2.20^{\mathrm{a}}$ & $21.06 \pm 2.69 \mathrm{~b}$ \\
Oil (\%) & $50.28 \pm 0.57^{1,2}$ & $45.56 \pm 1.05 \mathrm{~b}$ \\
Total Carbohydrates (\%) & $21.01 \pm 1.87^{\mathrm{a}}$ & $28.22 \pm 4.36 \mathrm{~b}$ \\
Ash (\%) & $2.18 \pm 0.17 \mathrm{a}$ & $2.86 \pm 0.17 \mathrm{~b}$ \\
\hline Moisture & $1.7 \pm 0.10 \mathrm{a}$ & $2.3 \pm 0.09 \mathrm{~b}$ \\
\hline Energetic Value & 635.88 & 607.16 \\
\hline
\end{tabular}

${ }^{1}$ Expressed on dry weight basis.

${ }^{2}$ Mean followed by the same letter within each row are not significantly different at $\alpha=0.05$.

Argentina. All samples were evaluated in a booths under fluorescent light at room temperature. Ten grams of the product sample were placed into plastic cups with lids coded with 3 digit random numbers. Panelist evaluated the samples plus a warm-up sample on the test day. The final lists of warm-up and reference intensity ratings and definitions were posted in the booths for the test session. Samples were tested using a complete randomized block design. The data were registered on paper ballots.

\subsection{Statistical Analysis}

The data were analyzed using the InfoStat sofware, version 1.1 (Facultad de Ciencias Agropecuarias, Universidad Nacional de Córdoba) software. Means and standard deviations were calculated. Analysis of variance was used to detect significant differences between samples in sensory attributes and chemical analysis using LSD tests to find significant differences $(\alpha=0.05)$ between means. In the paired preference test, binomial probability was used (Resurreccion, 1998): the null hypothesis, $\mathrm{H}_{0}: 1 / 2=p$; the alternative hypothesis, $\mathrm{H}_{\mathrm{a}}: p$ (HRP) $\neq p(\mathrm{RP})$. If the calculated $\mathrm{Z}$ score is not $>1.96$ ( $5 \%$ level of significance), therefore the $p$-value is less than 0.05 , so there is no evidence to reject the null hypothesis.

\section{RESULTS AND DISCUSSION}

\subsection{Chemical composition and energetic value}

One of the important crop plants in the world is the peanut. Peanuts contain about 50 to $55 \%$ oil and
25 to $28 \%$ protein (St. Angelo, 1996). For this reason, peanuts make an important contribution to the human diet in many countries because of their nutritional benefits to consumers (Bansal et al., 1993). The protein, oil, total carbohydrates and ash percentages are presented in Table III. Significant differences $(\alpha=0.05)$ in protein, oil and total carbohydrate contents were detected between HRP and RP. RP showed higher protein and oil percentages while HRP had a higher percentage of carbohydrates. The cause of these results was the layer of coating added to HRP which contains honey and sugar as its main compounds. In addition these results affected the energetic values of the products. HRP had a lower energetic value than RP due to its lower fat content.

\subsection{Consumer Analysis}

In the paired preference test, the percentages of preference were $51.8 \%$ in HRP and $48.2 \%$ in RP. In the binomial analysis of these data, the null hypothesis, $\mathrm{H}_{0}: p(\mathrm{HRP})=p(\mathrm{RP})$ was not rejected. Then, it was concluded that there was no perceptible difference in preference between the two products. The acceptance means from each group of preference product showed higher values in HRP $(7.13 \pm 1.11)$ than in $\mathrm{RP}(6.76 \pm 1.08)$.

Consumer testing is one of the most important activities in product development. The primary purpose of consumer tests is to assess the personal response by current and potential customers of a product, product ideas, or specific product characteristics. Consumer evaluation concerns itself with testing certain products using untrained people who are or will become the ultimate users of the 
Table IV

Mean of answer percentage for each point in hedonic scale and general average of the overall acceptance from consumer test of Honey Roasted Peanuts (HRP) and Roasted Peanuts (RP)

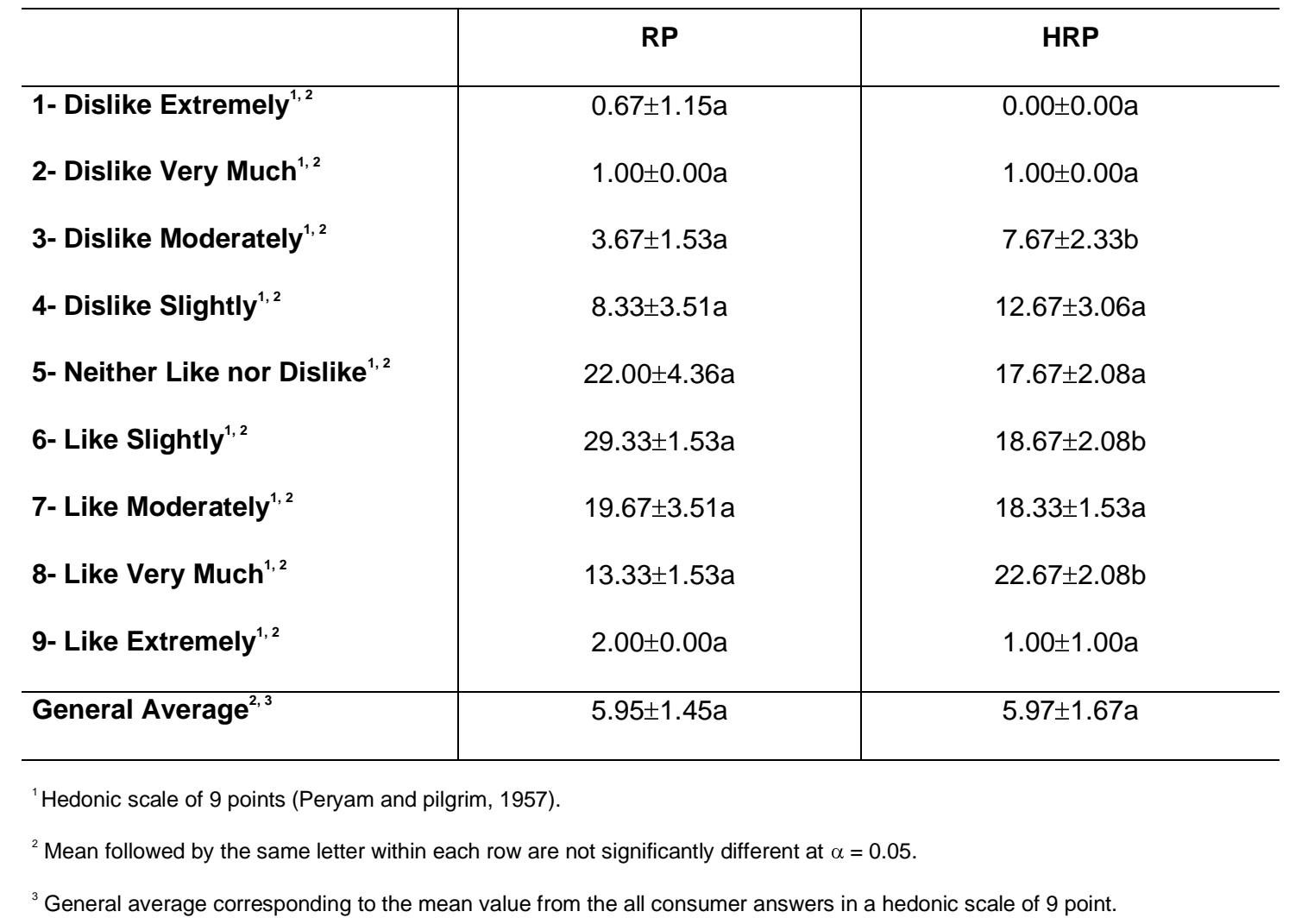

product. Consumer testing is necessary throughout the various stages of a product cycle. These stages include the development of the product itself, product maintenance, product improvement and optimazation, and assessment of market potential (Resurreccion, 1998). In this study, the consumer test was conducted to detect differences between products. The response percentage means for each point in the hedonic scale of the overall acceptance and general averages from consumer test in HRP and RP are presented in Table IV. Significant differences $(\alpha=0.05)$ in response percentage means of the overall acceptance between the products were found in point 6 (like slightly) and point 8 (like very much) in a hedonic scale of 9 points. The response percentages in point 6 and 8 were higher in RP and HRP, respectively. This result could be indicating that HRP would have a better overall acceptance but the general average is not significantly different between HRP and RP. In general, the products had an overall acceptance close to " 6 = like slightly" in an hedonic scale of 9 point. Grosso and Resurreccion (2002) found a slightly higher overall acceptance mean on cracker coated and roasted peanuts elaborated with American peanuts and evaluated by American consumers.

\subsection{Descriptive Analyses}

The mean values of the sensory attribute intensities from the descriptive analysis in HRP and $\mathrm{RP}$ are presented in Table $\mathrm{V}$. Eleven sensory attributes were described by the panelists of the trained sensory panel in HRP and RP. The attributes are the followings: for appearance: brown color and roughness; for aroma: roasted peanutty, oxidized, cardboard; for taste: sweet, salty, bitter and sour; and for texture: hardness and crunchiness.

Roughness, roasted peanutty, sweet, salty and hardness were the sensory attributes from the descriptive analysis which showed significant differences (at $\alpha=0.05$ ) between HRP and RP (Table V). The intensity of Roughness was higher in HRP (57.97 points in line scale of 0-150 points) due to the coating layer of honey with sugar and salt. Roasted peanutty is the attribute used to characterize peanut flavor in peanut products (Johnsen et al., 1988). This attribute showed higher intensity in RP. In HRP, the intensity of this attribute could have been partially covered up by other attributes like sweet and salty. Therefore, the panel detected roasted peanutty with less intensity in HRP. The attributes, sweet and salty had higher intensity in 
Table V

Mean of the sensory attribute intensities from descriptive analysis of Honey Roasted Peanuts (HRP) and Roasted Peanuts (RP)

\begin{tabular}{|c|c|c|}
\hline Sensory attributes & $\mathbf{R P}$ & HRP \\
\hline \multicolumn{3}{|l|}{ Appearance } \\
\hline 1- Brown Color ${ }^{1,2}$ & $43.89 \pm 1.98 \mathrm{a}$ & $42.31 \pm 6.51 \mathrm{a}$ \\
\hline 2- Roughness, & $38.03 \pm 2.22 a$ & $57.97 \pm 7.09 \mathrm{~b}$ \\
\hline \multicolumn{3}{|l|}{ Aromatics } \\
\hline 3- Roasted Peanutty, & $55.08 \pm 6.42 a$ & $48.28 \pm 9.07 \mathrm{~b}$ \\
\hline 4- Oxidized ${ }^{1,2}$ & $3.64 \pm 2.29 a$ & $4.36 \pm 3.45 a$ \\
\hline 5- Cardboard ${ }^{1,2}$ & $6.53 \pm 3.15 a$ & $6.31 \pm 3.05 \mathrm{a}$ \\
\hline \multicolumn{3}{|l|}{ Tastes } \\
\hline 6- Sweet ${ }^{1,2}$ & $14.58 \pm 2.59 a$ & $39.72 \pm 8.22 b$ \\
\hline 7- Salty ${ }^{1,2}$ & $8.19 \pm 2.66 a$ & $36.94 \pm 9.13 b$ \\
\hline 8- Bitter ${ }^{1,2}$ & $6.00 \pm 2.45 a$ & $6.53 \pm 3.21 \mathrm{a}$ \\
\hline 9- Sour ${ }^{1,2}$ & $1.27 \pm 1.03 a$ & $3.67 \pm 3.66 a$ \\
\hline \multicolumn{3}{|l|}{ Texture } \\
\hline 10- Hardness ${ }^{1,2}$ & $51.00 \pm 3.33 a$ & $48.72+3.85 b$ \\
\hline 11- Crunchiness ${ }^{1,2}$ & $41.06 \pm 4.04 a$ & $38.92 \pm 5.34 a$ \\
\hline
\end{tabular}

${ }^{1}$ Intensity ratings are based on $150 \mathrm{~mm}$ unstructured line scales.

${ }^{2}$ Mean followed by the same letter within each row are not significantly different at $\alpha=0.05$.

HRP because of its coating layer containing sugar and salt. These values could have influenced the results of consumer acceptability (Table IV). The intensity of hardness was lower in HRP. The higher moisture in HRP (Table III) due to the syrup solution used to prepared the product could be the cause of the lower hardness intensity.

Johnsen et al. (1988) developed a basic lexicon for the description of peanut flavor. The lexicon is intended to provide a means of communication among the peanut grower, the peanut industry, the peanut researcher and peanut manufacturers. The roasted peanutty attribute is used to characterize the typical roasted peanut flavor. Roasted peanutty flavor can be attributed to the presence of pyrazines (Buckholz and Daun, 1981; Crippen et al., 1992). Bett and Boylston (1992) found that roasted peanutty flavor intensity and alkylpyrazines decreased in stored roasted peanuts. Warner et al. (1996) and
Brannan et al. (1999) also found that roasted peanutty flavor decreased in stored roasted peanuts. Meilgaard et al. (1991) reported a roasted peanutty intensity of 7 in an scale of 1-15 points equivalent to 70 in a scale of 0-150 points for American peanuts. Grosso and Resurreccion (2002) found that the roasted peanutty intensity was 67 and 63 in Roasted Peanuts and Cracker Coated Peanuts, respectively, also in American peanuts. In this work, the intensities of roasted peanutty in HRP and RP were 55.08 and 48.28, respectively. Another important attribute used to characterize the flavor of peanuts is sweet. This attribute showed an intensity of 14.58 in RP. In American Peanuts, the intensity of sweet attribute was 7 (Grosso and Resurreccion, 2002). These results indicate that the flavor of American peanuts is clearly different from Argentinean peanuts especially for the intensities of sweet and roasted peanutty attributes. 
Oxidized, cardboard and painty flavors are sensory attributes associated with chemical changes ocurring during the lipid oxidation (Warner et al., 1996). Bett and Boylston (1992) detected that cardboard flavor intensity had a linear increase across storage time in roasted peanuts. Muego-Gnanasekharan and Resurreccion (1992) detected that oxidized and cardboard flavor intensities exhibited a linear increase during storage time in peanut paste. Warner et al. (1996) observed that oxidized flavor intensity increased during storage time in ground roasted peanuts. In this work, the intensity of oxidized and cardboard in RP and HRP were very low because the analyzed products were fresh without storage.

\section{ACKNOWLEDGEMENTS}

We want to thank Lorenzati, Ruetsch and CIA from Ticino, Córdoba, Argentina for providing the peanuts. This work was supported by SECYT-UNC.

\section{REFERENCES}

Ahmed, E. H. and Youngen, C. T. (1982). Composition, Quality, and Flavor of Peanuts in Peanut Science and Technology, p. 655-688, H. E. Pattee and C. T. Young, (Eds.)., American Peanut Research and Education Society Inc., Yoakum, Texas, USA.

Asiedu, J. J. K. B. (1994). Industrial Utilization and Processing in The Groundnut Crop, p. 480-508, J. Smartt, (Ed.)., Chapman \& Hall., London, UK.

AOAC (1980). Official Methods of Analysis, 13th ed., W. Horwitz, (Ed.)., Association of Official Analytical Chemists., Washington, DC., USA.

Baker, A. R., Baldwin, E. A. and Nisperos-Carriedo, M. O. (1994). Edible coatings and films for processed foods in Edible Coatings and Films to Improve Food Quality, p. 89-104, J. M. Krochta, A. R. Baldwin, and M. O. Nisperos-Carriedo, (Eds.)., Technomic Publ. Co., Lancaster, Pensilvania, USA.

Bansal, U. K., Satija, D. R. and Ahuja K. L. (1993). Oil composition of diverse groundnut (Arachis hypogaeae L.) genotypes in relation to different environments. $J$. Sci. Food Agric. 63, 17-19.

Bett, K. L. and Boylston, T. D. (1992). Effect of storage on roasted peanut quality in Lipid Oxidation in Food, p. 322-343, A. J. St. Angelo, (Ed)., ACS Symposium Series 500, American Chemical Society., Washington, DC, USA.

Brannan, G. L.; Koehler, P. E. and Ware, G. O. (1999). Physico-chemical and sensory characteristics of defatted roasted peanuts during storage. Peanut Sci., 26, 44-53.

Buckholz, L. L. and Daun, H. (1981). Instrumental and sensory characteristics of roasted peanut flavor volatiles in Quality of selected fruits and vegetables, $\mathrm{p}$. 163-181, R. Teranishi, H. Barrera-Benitez, (Eds.)., ACS Symposium Series 170, American Chemical Society., Washington, DC, USA.

Crippen, K. L.; Vercellotti, J. R.; Lovegren, N. V.; Sanders, T. H. (1992). Defining roasted peanut flavor quality. Part. 2. Correlation of GC volatiles and sensory flavor attributes in Food Science and Human Nutrition., p. 211-227, G. Charalambous, (Ed.)., Elsevier Science Publisher BV., Amsterdam.

Gills, L. A. and Resurreccion, A. V. A. (2000). Sensory and physical properties of peanut butter treated with palm oil and hydrogenated vegetable oil to prevent oil separation. J. Food Sci., 65, 173-180.

Grosso, N. R. and Guzmán, C. A. (1995). Chemical composition of aboriginal peanut (A. hypogaea) seeds from Perú. J. Agric. Food Chem., 43, 102-105.

Grosso, N.R. and Resurreccion, A.V.A. (2002). Predicting consumer acceptance ratings of cracker-coated and roasted peanuts from descriptive analysis and hexanal measurements. J.Food Sci., 67, 1530-1537.

Johnsen, P. B.; Civille, G. V.; Vercellotti, J. R.; Sanders, T. H. and Dus, C. A. (1988). Development of a lexicon for the description of peanut flavor. J. Sensory Studies, 3, 9-17.

Meilgaard, M.; Civille, G.V. and Carr, B. T. (1991). Sensory Evaluation Techinques. $2^{\text {nd }}$ ed., CRC Press Inc., Boca Raton, Florida.

Muego-Gnanasekharan, K. F. and Resurrección, A. V. A. (1992). Physicochemical and sensory characteristic of peanut paste stored at different temperatures. J. Food Sci., 57, 1385-1389.

Peryam, D. R. and Pilgrim, F. J. (1957). Hedonic scale method of measuring food preferences. Food Technol., 11, 9-14.

Plemmons, L. E. and Resurreccion, A. V. A. (1998). A warm-up sample improves reliability of responses in descriptive analysis. J. Sensory Studies, 13, 359-376.

Resurreccion, A. V. A. (1998). Consumer Sensory Testing for Product Development. Aspen Publisher Inc., Gaithersburg, Maryland.

St. Angelo, A. J. (1996). Lipid oxidation in food. Critical Reviews in Food Science and Nutrition, 36, 175-224.

Warner, K. J. H.; Ddimick, P. S.; Ziegler, G. R.; Mumma, R.O. and Hollender, R. (1996). Flavor-fade and off flavor in ground roasted peanuts as related to selected pyrazines and aldehydes. J. Food Sci., 61, 496-472.

Woodroof, J. G. (1983). Peanuts. Production, Processing, Products. $3^{\text {rd }}$ Ed. AVI Publishing Company Inc., Westport, Connecticut.

Young, C. T. and Hammons, R. O. (1973). Variations in the protein levels of a wide range of peanut genotypes (Arachis hypogaea L.). Oleagineux, 28, 293-297. 